\title{
Free-free resonance method for the mechanical characterization of carbonate rocks used as building stones
}

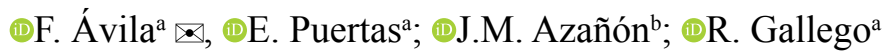 \\ a. Dept. of Structural Mechanics and Hydraulic Engineering, University of Granada, (Granada, Spain) \\ b. Dept. of Geodynamics, University of Granada, Campus Universitario Fuentenueva, (Granada, Spain) \\ ๔: favila@ugr.es
}

Received 19 February 2021

Accepted 18 August 2021

Available on line 18 February 2022

\begin{abstract}
Nondestructive testing techniques have attracted growing interest in the last few years due to their ability to assess material properties without damaging the specimens. The free-free resonance method is a nondestructive testing technique based on the analysis of the natural frequencies of a sample. This study presents and discusses the applicability of this technique, traditionally used on soils, for the mechanical characterization of rocks. With this aim, the free-free resonance method is used to obtain the dynamic elastic modulus and shear modulus of four carbonate rocks that have been widely used as construction materials in southern Spain. The results from the nondestructive evaluation of dry and saturated rocks, in combination with petrographic characterization and uniaxial compression tests, make it possible to assess the existing relationships between the mechanical properties of carbonate rocks and to evaluate the impact of porosity and moisture content on their mechanical behavior.
\end{abstract}

KEYWORDS: Limestone; Sandstone; Mechanical properties; Characterization; Free-Free Resonance (FFR).

Citation/Citar como: Ávila, F.; Puertas, E.; Azañón, J.M.; Gallego, R. (2022) Free-free resonance method for the mechanical characterization of carbonate rocks used as building stones. Mater. Construcc. 72 [345], e276. https://doi.org/10.3989/mc.2022.03421.

RESUMEN: Método de la frecuencia de resonancia para la caracterización mecánica de rocas carbonáticas usadas como piedras de construcción. Las técnicas de ensayo no destructivo están atrayendo un creciente interés durante los últimos años debido a su capacidad para evaluar las propiedades sin dañar el espécimen. El Método de la Frecuencia de Resonancia es una técnica de ensayo no destructiva basada en el análisis de las frecuencias naturales de una muestra de material. Este estudio presenta y discute la aplicabilidad de esta técnica, tradicionalmente utilizada en suelos, para la caracterización mecánica de rocas. Con este objetivo, el Método de la Frecuencia de Resonancia es utilizado para obtener el módulo elástico dinámico y el módulo cortante dinámico de cuatro rocas carbonáticas ampliamente utilizadas como material de construcción en el sur de España. Los resultados de la evaluación no destructiva en rocas secas y saturadas, combinados con una caracterización petrográfica y ensayos de compresión uniaxial, permiten determinar las relaciones existentes entre las propiedades mecánicas de dichas rocas carbonáticas, así como evaluar el impacto de la porosidad y el contenido de humedad en su comportamiento mecánico.

PALABRAS CLAVE: Caliza; Arenisca; Propiedades mecánicas; Caracterización; Frecuencias de Resonancia (FFR).

Copyright: (C2022 CSIC. This is an open-access article distributed under the terms of the Creative Commons Attribution 4.0 International (CC BY 4.0) License. 


\section{INTRODUCTION}

To evaluate the mechanical properties of construction materials, diverse invasive and destructive techniques have been traditionally applied. The main disadvantage of these conventional techniques is that their application requires the destruction of the sample, which is detrimental to the development and maintenance of the structures (1) and is unacceptable in some situations (e.g., for historical buildings) $(2,3)$

With the aim of avoiding the destruction and deterioration of the tested material, since the 20th century, and especially over the last few decades, several nondestructive testing (NDT) techniques have been developed $(1,3,4)$. These methods make it possible to calculate the material properties without permanently modifying its characteristics $(5,6)$.

The application of NDT is, therefore, especially interesting in the case of architectural heritage. One of the most common NDT techniques to estimate the mechanical properties of building materials is the ultrasonic pulse velocity (UPV) method, which has been proved to be useful to identify the mechanical properties, anisotropy, compactness and presence of discontinuities in rocks (7-11). Several works have applied this technique to assess the state of conservation of historical buildings $(8,12-14)$. UPV also has been used in combination with other NDT techniques, such as ground-penetrating radar, which has a wide range and allows high resolution of up to ten centimeters from a centimeter (14), and the Leeb rebound hardness test (7). These combinations of two NDT techniques can provide more information than a single technique, particularly if they are sensitive to different parameters (15). In addition to the standard mechanical characteristics, other material properties can be determined via NDT, such as optical surface microroughness and air permeability (12).

This paper presents the application of another NDT technique, the so-called free-free resonance (FFR) method or free-free resonance frequency method, to calculate the mechanical properties of rocks that are commonly used as construction materials. The FFR testing technique consists of vibrating a material sample to determine its natural frequencies and then using these data to calculate the modulus of elasticity and shear modulus of the tested material $(16,17)$. Although FFR is an NDT technique (the specimen is not destroyed), the methodology requires the extraction of a material sample, so it can be considered an invasive procedure when applied to existing structures.

The FFR technique has been used in previous studies (17-19) to determine the dynamic mechanical properties of cohesive and stabilized soils. Resonant frequency-based methods have also been used in some recent studies to evaluate the elastic properties of other materials, such as rocks $(20,21)$, blockin-matrix rocks $(22)$ or concrete $(23,24)$.
The aim of the present study is to extend the application of the FFR methodology to characterize the mechanical properties of building stones. In this regard, four carbonate rocks were analyzed. These rocks were chosen because they have been traditionally used as construction materials in Andalusia (southern Spain) and other Mediterranean regions, so they are present in several historic masonry buildings (25-28). In addition to the FFR tests, uniaxial compression tests (UCTs) were carried out to calculate the compressive strength of the rocks. The results from the tests were used to analyze the relationship between the mechanical properties and the impact of porosity on the mechanical behavior. FFR tests were carried out for both dry and saturated specimens to evaluate the effect of humidity on the material properties.

\section{MATERIALS AND METHODS}

\subsection{Description of materials}

In the present study, four carbonate rocks were evaluated: white Macael marble, Santa Pudia limestone, Albox travertine and Ronda sandstone. All of them are autochthonous from Andalusia (Spain) and have been frequently used as construction material within the region.

White Macael marble (WM), quarried in the Macael area of Almeria (Spain), is a Late Triassic marble belonging to the Nevado-Filabride Complex in the Spanish Betic Internal Zone (29) and is the only metamorphic rock considered in this study. WM is a pearly white stone, presenting gray foliation composed of muscovite, amphibole, epidote, titanite and deformed carbonate grains (30). In mineralogical terms, it consists predominantly of calcite $\left(\mathrm{CaCO}_{3}\right.$, $97 \%$ ) and approximately $3 \%$ of pyrite (SFe). Its texture, obtained by means of a petrographic microscope, is porphyroblastic with grain sizes of $0.5 \mathrm{~mm}$ to $1 \mathrm{~mm}$ and pore sizes lower than $0.001 \mathrm{~mm}$, with porosities of ca. $1.8 \%(26,31)$. This stone is one of the most commonly used marbles in Spain and is widely used as an ornamental stone in Spanish architectural heritage, including masterpieces such as the fountain of the Lions in the Alhambra (Granada) $(26,31,32)$.

Santa Pudia limestone (SPL) is a whitish bioclastic limestone quarried in Escuzar, Granada (Spain), in a depression that forms an intramountain Neogene basin. It is constituted by remains of benthic and planktonic foraminifera skeletons, which lead to a mineralogical composition with $95 \% \mathrm{CaCO}_{3}$. SPL has a grain size of $0.5 \mathrm{~mm}$ to $1 \mathrm{~mm}$ and high well-connected matrix porosity (approximately $33 \%$, mostly open porosity), with intergranular pores of approximately $1 \mathrm{~mm}$, larger moldic pores of 
up to $4 \mathrm{~mm}$ and some small intergranular cemented pores $(0.1 \mathrm{~mm})(33)$. This rock has been widely used in the construction of historic buildings in Granada, such as the cathedral, the palace of Carlos V in the Alhambra and the Royal Hospital, due to its easy workability, although its high porosity considerably reduces its durability $(28,33)$. Today, it is mainly used in restoration works.

Albox travertine (AT) is a limestone quarried in the municipal district of Albox, Almeria (Spain), from Quaternary formations, appearing over Pleistocene, Pliocene and Miocene materials (28). Its mineralogical composition consists of $\mathrm{CaCO}_{3}$ (92\%) and opaque and detrital materials ( $8 \%$ ); it has a micrite texture with homogeneous grain size $(0.02 \mathrm{~mm})$ and large elongated and oriented pores $(0.02 \mathrm{~mm}$ to $4 \mathrm{~mm}$ ). The total porosity of the rock is equal to $14.3 \%$, of which $11.2 \%$ is open porosity and $3.1 \%$ is closed porosity (33). This material is commonly used in modern architecture and in the restoration of historic buildings (34) due to its similarity to the Alfacar travertine, which has been used in Andalusia since antiquity. AT can be considered a high-strength abrasion-resistant material, with a pore system that prevents the capillary rise of water (28).

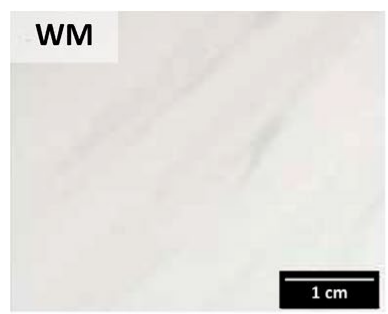

(1a)

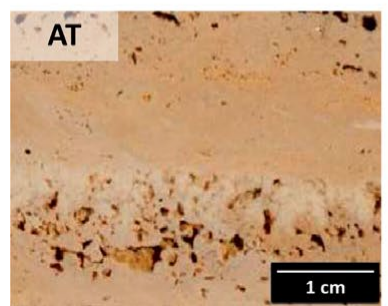

(3a)

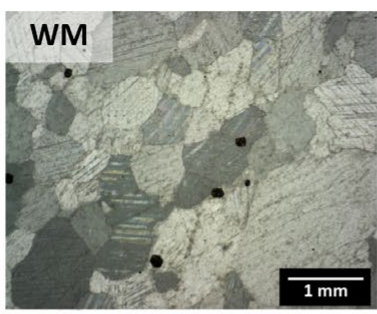

(1b)

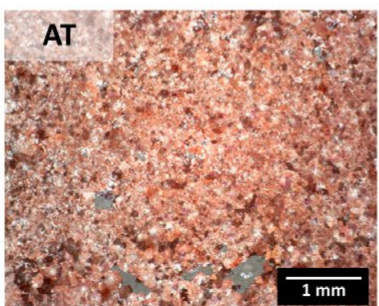

(3b)
Ronda sandstone (RS) is a carbonate arkosic sandstone with a light pink-whitish color, quarried approximately $5 \mathrm{~km}$ northeast of the town of Ronda, Malaga (Spain). The Ronda Basin, located over the northwestern Subbetic Units, is one of the largest piggyback basins in the Western Betics, with a sedimentary infill from the late Miocene (27). It is composed of $70 \%$ $\mathrm{CaCO}_{3}$ and $30 \%$ feldspar and quartz; its grain size is approximately $0.03 \mathrm{~mm}$, and its pore size is $<0.01 \mathrm{~mm}$. The cement in this rock is abundant, and sometimes two cementation phases can be distinguished: the first phase consolidates the calcarenite, which is deposited in the gaps between the clasts, and the second phase occurs when the cracks appearing in the material are filled. It has a porosity of approximately $17 \%$, mostly open (27). This stone has been used in the construction of several masonry historic buildings within the area of Ronda and has been used as an ornamental stone for cobbles, facades, benches or fountains.

The macroscopic and microscopic aspects of the four rocks under consideration are shown in Figure 1, while their main physical properties are summarized in Table 1. The petrographic and mineralogical study was conducted on thin sections under an Olympus BX-60 transmitted light optical microscope. The

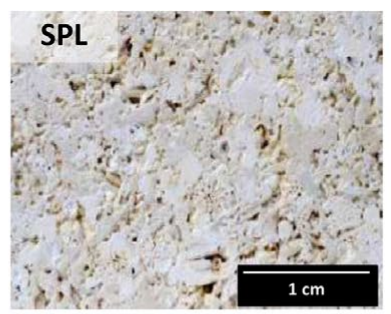

(2a)

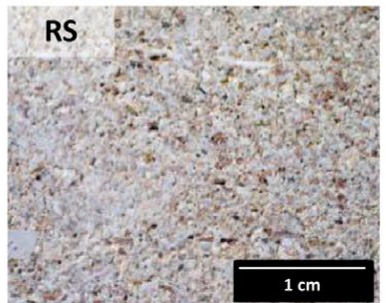

(4a)

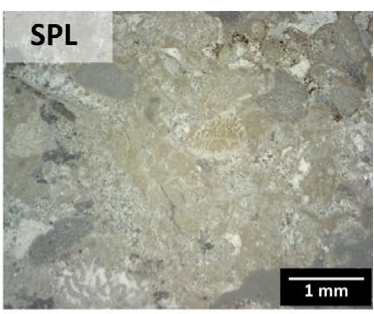

(2b)

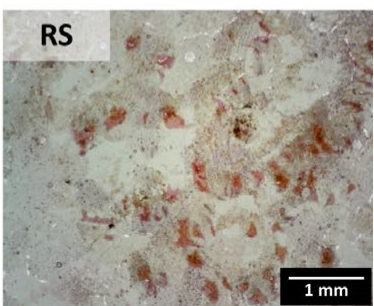

(4b)

FIGURE 1. Macroscopic aspect of a polished sample (a) and polarization optical microscope image (crossed polars) (b) of the rocks under study: (1) Macael coarse-grained and homogeneous marble in appearance, alternating between white and grey tones (black cubic inclusion are pyrite crystals); (2) Santa Pudia bioclastic limestone (biosparite to biorrudite with bryozoa and red algae); (3) Albox heterogranular crystalline limestone type travertine; (4) Ronda carbonate sandstone with a massive texture.

TABLE 1. Physical characteristics of the considered rocks: grain and pore size, porosity $(n)$, real density $\left(\rho_{r}\right)$ and bulk density $\left(\rho_{b}\right)$.

\begin{tabular}{lccccc}
\hline Rock & Grain size $[\mathrm{mm}]$ & Pore size $[\mathrm{mm}]$ & $n[\mathrm{vol} \%]$ & $\rho_{r}\left[\mathrm{~g} / \mathrm{cm}^{3}\right]$ & $\rho_{b}\left[\mathrm{~g} / \mathrm{cm}^{3}\right]$ \\
\hline WM & $0.5-1$ & $<0.001$ & 1.8 & 2.72 & 2.68 \\
\hline SPL & $0.5-1$ & $0.1-4$ & 33.0 & 2.62 & 1.73 \\
\hline AT & 0.02 & $0.02-4$ & 8.0 & 2.62 & 2.42 \\
\hline RS & 0.03 & $<0.01$ & 17.0 & 2.63 & 2.17 \\
\hline
\end{tabular}


thin sections in Figure 1 were stained with alizarin to identify calcite.

The preparation of the specimens for the FFR tests was performed according to the indications established by the standard UNE-EN 14146 (16), which defines the methodology followed in the present study for the execution of FFR tests. The samples were cut using a circular saw in the direction perpendicular to the penetrative planar fabric. The dimensions of the rock samples were $200 \mathrm{~mm} \times 50 \mathrm{~mm} \times 50 \mathrm{~mm}$, except for the AT, which had slightly different dimensions $(145 \mathrm{~mm} \times 70 \mathrm{~mm} \times 70 \mathrm{~mm})$. Three to five samples of each rock were tested. All samples were measured and weighed before the tests and marked to indicate the position of the brackets, accelerometers and impact points.

\subsection{FFR method: Basis and description}

The FFR method is an NDT technique used to calculate the dynamic modulus of elasticity and shear modulus of a material by the mechanical excitation of a test sample with a defined geometry (17). The excitation was applied following the impact method, which consists of hitting the specimen with an impactor and recording the response using an accelerometer.

The impact excites all frequencies of the sample at the same time. This response, registered by the accelerometer, is then amplified and transmitted to a waveform analyzer that decomposes the signal via Fourier transform. In this way, it is possible to identify the natural frequencies of the tested sample as those generating resonance effects.
The test was carried out in both transverse and longitudinal modes to obtain the modulus of elasticity, and in torsional mode to obtain the shear modulus. The experimental setup for these three different modes is shown in Figure 2. When performing the tests, the brackets must be placed in the points where nodes are expected according to the tested mode, so the boundary conditions of the sample are not modified. Additionally, impacts and accelerometers must be placed in those points where a maximum is expected.

Once the frequencies are determined, it is possible to calculate the dynamic elastic modulus and shear modulus of the material by applying the formulae indicated in the aforementioned standard UNEEN 14146 (16):

$$
\begin{gathered}
E_{d, L}=4 \cdot 10^{-6} l^{2} f^{2} \rho T \\
E_{d, t}=\left(4 \cdot 10^{-6} \pi^{2} l^{4} f^{2} \rho C\right) /\left(4.72^{4} i^{2}\right) \\
G=4 \cdot 10^{-6} l^{2} f^{2} \rho R
\end{gathered}
$$

where $E_{d, L}$ and $E_{d, t}$ are the dynamic modulus of elasticity (in $\mathrm{MPa}$ ) calculated via longitudinal and transverse modes, respectively; $G[\mathrm{MPa}]$ is the dynamic shear modulus; $l[\mathrm{~mm}]$ is the length of the sample; $f[\mathrm{~Hz}]$ is the natural frequency for each test mode; $\rho\left[\mathrm{kg} / \mathrm{m}^{3}\right]$ is the material bulk density; $i[\mathrm{~mm}]$ is the radius of gyration of the sample; and $T, C$ and $R$ are correction coefficients defined in (16).

The equipment used to perform the tests was composed of the following items:

- An impact hammer Bruel \& Kjaer model 8206003: voltage sensitivity $=1.14 \mathrm{mV} / \mathrm{N}$; fullscale force range compression $=4448 \mathrm{~N}$; $\max$.

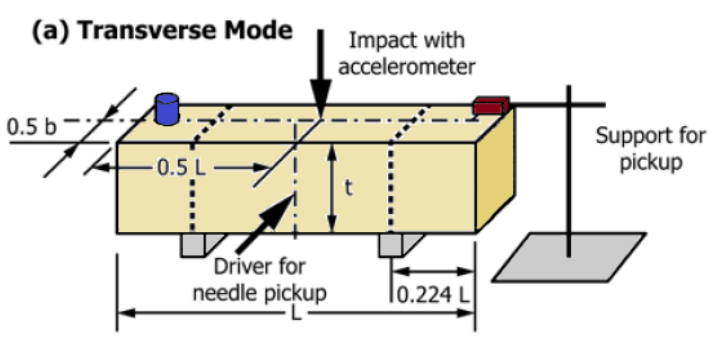

(c) Torsional Mode

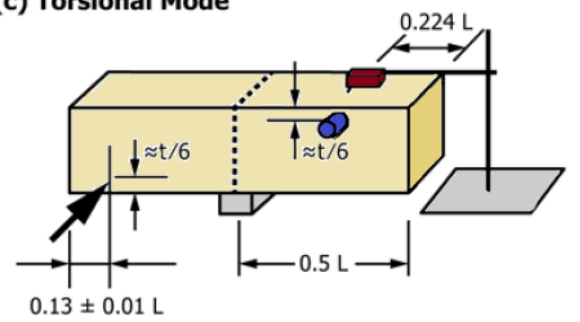

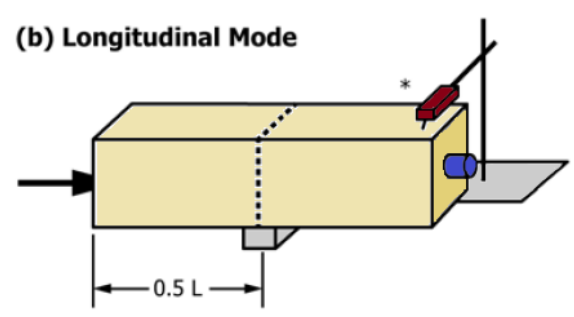

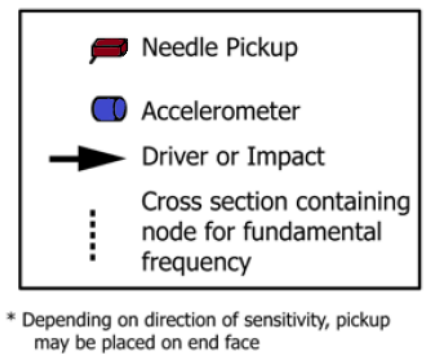

may be placed on end face

FigURE 2. FFR test procedure for each mode of vibration. Adapted from ASTM C215-14 (41). 
force compression $=8896 \mathrm{~N}$; effective seismic $\operatorname{mass}=100 \mathrm{~g}$; max. frequency $=600 \mathrm{kHz}$.

- Two piezoelectric accelerometers Bruel \& Kjaer model 4514-B-001: titanium hexagonal head; voltage sensibility $=100 \mathrm{mV} / \mathrm{g}$; measuring range $=50 \mathrm{~g}$; transverse sensitivity $<5 \%$.

- A 12-channel input module, model LAN XI 12 PULSE 3053b.

The impact range was fixed at $10 \mathrm{~s}$, enough to perform three to four impacts, with a strength of $350 \mathrm{~N}$ per impact. The tests for each vibration mode were repeated until three valid responses were obtained. A response was considered valid when the natural frequencies were clearly recognizable. The mean of these three results was considered the reference value to be used for the calculation of the material properties.

With the aim of fully characterizing the materials under consideration, the FFR test was also carried out on water-saturated samples. The specimens were first tested in dry conditions and then submerged until saturation according to standard UNE-EN 13755 (35), and the test was repeated for the saturated specimens following the same procedure.

\subsection{Uniaxial compression tests}

In addition to the FFR tests, conventional uniaxial compression tests (UCTs) were carried out to obtain the compressive strength of the rocks under analysis. This test was performed according to the standard UNE-EN 1926:2007 (36).

For this test, five cubic $40 \mathrm{~mm}$-side samples of each material were used. These samples were subjected to uniaxial compression until failure by the application of a vertical force using a hydraulic testing machine for high-strength materials. The compressive strength of the material $\left(\sigma_{c}\right)$ can be obtained as the ratio between the applied force $(F)$ and the surface of the sample where that load is applied $(S)$. The results from the UCT are used to assess the relationship between the dynamic modulus and the compressive strength for rocks characterized by their high calcite content.

\section{RESULTS AND DISCUSSION}

\subsection{Test results in dry conditions}

The results obtained from the nondestructive FFR tests are shown in Table 2. Poisson's ratio $(v)$ was calculated according to Equation [4], considering the modulus of elasticity obtained via the longitudinal mode of the test. These results are consistent with the values obtained by several authors (37-40) for rocks with similar characteristics.

$$
E=2 G(1-v)
$$

As shown in Table 2, the modulus of elasticity was calculated by both longitudinal and transversal modes. The values obtained via the longitudinal mode were $3 \%$ to $10 \%$ greater than those obtained via the traversal mode. It is possible that these variations were caused by the anisotropy of the materials; in this regard, previous studies indicate a total anisotropy for P waves $\left(\Delta M_{P}\right)$ of $13.0 \%$ for WM (26), $9.2 \%$ for SPL, $1.5 \%$ for AT (28) and $10.2 \%$ for RS (27). However, no direct relationship is observed between these anisotropy values and the variation in the elastic modulus between the longitudinal and transverse tests (WM: $5.1 \%$; SPL: $7.0 \%$; AT: $5.7 \%$; RS: $6.9 \%$ ). These results, together with the fact that every sample tested showed greater values for the elastic modulus obtained via longitudinal mode, suggest that this variation might not be related to the anisotropy but could be inherent to the methodology. In this regard, standard ASTM C215-14 (41) indi-

TABLE 2. Average value and standard deviation (SD) of the natural frequencies and mechanical properties obtained from FFR tests in dry conditions. Elastic modulus calculated via longitudinal $\left(E_{d, L}\right)$ and transversal $\left(E_{d, T}\right)$ mode, shear modulus $(G)$ and Poisson's ratio $(v)$.

\begin{tabular}{|c|c|c|c|c|c|c|c|c|}
\hline & & \multicolumn{3}{|c|}{ Frequencies [kHz] } & \multicolumn{4}{|c|}{ Mechanical properties } \\
\hline Rock & & Long. & Trans. & Tors. & $E_{d, L}[\mathrm{GPa}]$ & $E_{d, T}[\mathrm{GPa}]$ & $G[\mathrm{GPa}]$ & $v[-]$ \\
\hline \multirow{2}{*}{ WM } & Avg. & 14.35 & 6.31 & 7.75 & 89.58 & 85.01 & 30.79 & 0.45 \\
\hline & $\mathrm{SD}$ & 0.14 & 0.13 & 0.05 & 1.54 & 0.76 & 0.36 & 0.01 \\
\hline \multirow{2}{*}{ SPL } & Avg. & 5.63 & 2.05 & 3.26 & 13.93 & 12.95 & 5.51 & 0.26 \\
\hline & $\mathrm{SD}$ & 0.06 & 0.03 & 0.04 & 0.40 & 0.28 & 0.17 & 0.01 \\
\hline \multirow{2}{*}{ AT } & Avg. & 15.57 & 10.30 & 9.36 & 51.90 & 48.92 & 21.25 & 0.22 \\
\hline & $\mathrm{SD}$ & 0.29 & 0.07 & 0.19 & 3.81 & 2.13 & 1.22 & 0.03 \\
\hline \multirow{2}{*}{ RS } & Avg. & 8.58 & 3.72 & 4.93 & 25.49 & 23.74 & 9.92 & 0.29 \\
\hline & $\mathrm{SD}$ & 0.06 & 0.03 & 0.03 & 0.32 & 0.37 & 0.10 & 0.00 \\
\hline
\end{tabular}


cates that different computed values for the dynamic modulus of elasticity may result from different modes of vibration. In the present study, the results of the elastic modulus in the transverse tests were $5 \%$ to $7 \%$ lower than those obtained in the longitudinal tests, and this difference was greater for rocks with higher porosity.

Some previous studies have used other NDTs, mostly ultrasonic pulse velocity tests, to assess the mechanical properties of these rocks, as shown in Table 3. Molina et al. (42) obtained very similar results for the elastic modulus $(+1.2 \%)$ and shear modulus $(-5.6 \%)$ of SPL and for the elastic modulus of AT (-9.1\%). Another study carried out by the same authors regarding RS (27) obtained elastic and shear moduli 3 to $4 \mathrm{GPa}$ higher than those obtained in the present study. Urosevic et al. (28) also used UPV to evaluate Alfacar travertine, very similar to AT, and obtained an elastic modulus of $59.57 \mathrm{GPa}$, very close to the value assessed via FFR (51.9 GPa). Some existing works regarding various types of Macael marble $(43,44)$ indicate elastic properties of the same order of magnitude as the values obtained in the present study, although slightly lower. These small differences, considering the intrinsic variability in the mechanical properties of a natural material such as stone, reinforce the hypothesis of the validity of the FFR methodology for mechanical characterization. It is important to note, however, that greater variation is observed in the values of Poisson's ratio, especially for AT but also significant for the other rocks under consideration.

The differences observed between both NDT methods might also be related to the anisotropy of the specimens. For anisotropic materials, such as rocks, FFR has certain advantages over other NDT techniques commonly used for the calculation of the same mechanical properties, as is the case with ultrasonic methods. The latter requires data from the celerity of P- and S-waves, which have orthogonal oscillating directions, so the anisotropy in the orthogonal planes affects the results in the direction under consideration. The FFR method, in contrast, works with only a stationary wave for each mode, so a potential anisotropy in the orthogonal planes does not affect the studied direction, and the elastic properties of the sample in the desired direction can be determined without interference.

The values obtained for the compression strength of the materials via UCT are shown in Table 4. These values were used to determine the relations between the diverse parameters obtained for the carbonated rocks.

It is possible to observe that the WM and AT showed excellent mechanical properties, with high values of compressive strength and elastic modulus, as a result of their high compactness and low porosity with poorly connected pores. This optimal mechanical behavior, together with their better durability due to the absence of clay and low water ab-

TABLE 3. Comparison between the mechanical properties obtained in the FFR tests and the results obtained via other NDT in previous studies.

\begin{tabular}{|c|c|c|c|c|c|c|c|c|c|c|c|c|}
\hline & \multicolumn{3}{|c|}{ WM } & \multicolumn{3}{|c|}{ SPL } & \multicolumn{3}{|c|}{ AT } & \multicolumn{3}{|c|}{ RS } \\
\hline Ref. & $\begin{array}{c}E_{d, L} \\
{[\mathrm{GPa}]}\end{array}$ & $G[\mathrm{GPa}]$ & $v[-]$ & $\begin{array}{c}E_{d, L} \\
{[\mathrm{GPa}]}\end{array}$ & $G[\mathrm{GPa}]$ & $v[-]$ & $\begin{array}{c}E_{d, L} \\
{[\mathrm{GPa}]}\end{array}$ & $G[\mathrm{GPa}]$ & {$[-]$} & $\begin{array}{c}E_{d, L} \\
{[\mathrm{GPa}]}\end{array}$ & $G[\mathrm{GPa}]$ & $v[-]$ \\
\hline FFR & 89.58 & 30.79 & 0.45 & 13.93 & 5.51 & 0.26 & 51.90 & 21.25 & 0.22 & 25.49 & 9.92 & 0.29 \\
\hline$(44)^{*}$ & 74.00 & - & - & - & - & - & - & - & - & - & - & - \\
\hline$(43)^{*}$ & 73.41 & - & 0.35 & - & - & - & - & - & - & - & - & - \\
\hline$(42)$ & - & - & - & 14.10 & 5.20 & 0.35 & 47.20 & 17.60 & 0.34 & - & - & - \\
\hline$(28)$ & - & - & - & 21.30 & - & 0.35 & 59.57 & - & 0.29 & - & - & - \\
\hline$(27)$ & - & - & - & - & - & - & - & - & - & 29.90 & 11.90 & 0.26 \\
\hline
\end{tabular}

${ }^{*}$ Rocks similar to the ones analyzed in the present study, but not the same.

TABLE 4. Average value and standard deviation (SD) of compressive strength of the rock samples obtained from UCT and estimated values from FFR tests.

\begin{tabular}{lllll}
\hline & \multicolumn{2}{l}{$\sigma_{c}[\mathrm{MPa}]$ from $\mathrm{UCT}$} & \multicolumn{2}{l}{$\sigma_{c}[\mathrm{MPa}]$} \\
\hline Rock & Avg. & SD & Long. & Tors. \\
\hline WM & 80.55 & 2.09 & 81.82 & 79.31 \\
\hline SPL & 9.24 & 0.54 & 8.08 & 7.23 \\
\hline AT & 63.42 & 11.87 & 60.12 & 63.72 \\
\hline RS & 28.95 & 1.64 & 32.04 & 31.84 \\
\hline
\end{tabular}


sorption potential (39), are why they have achieved such widespread use in construction within the region throughout history $(26,32,33)$. In contrast, RS and, especially, SPL are rocks with lower mechanical properties. In addition, these rocks often present durability problems due to their high porosity, presence of smectite clay and high water absorption and saturation capacity $(27,39)$. Actually, workability, not strength, is why these rocks have been frequently used in construction (38).

\subsection{Relations between parameters}

With the data obtained from the laboratory tests, the potential relations between the material properties were evaluated. In particular, a correlation between the modulus of elasticity and the compressive strength is expected, and a correlation is also expected between the intrinsic properties of the rocks, such as porosity, and their mechanical behavior (45).

Although the four rocks under study were carbonate rocks with comparable real density values and similar mineralogical compositions (except RS, which has ca. 30\% feldspar and quartz), there are some differences in their microstructure that must be considered. These differences are especially significant for marble, which is microstructurally totally different from sedimentary rocks such as sandstones, travertines and limestones. However, the results of

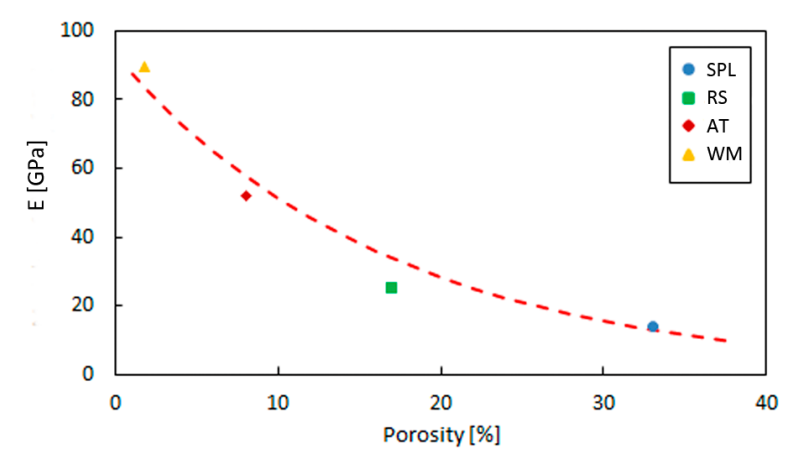

(a) the present study indicate that porosity can be considered the key parameter that acts as a distinctive factor to determine the modulus of elasticity and the compressive strength of the material. The relevance of porosity to the mechanical behavior has already been noted in previous studies comparing rocks with similar mineralogical characteristics $(40,45,46)$. The crucial role played by porosity can be clearly observed when representing the dynamic modulus of elasticity (obtained via longitudinal mode), the shear modulus and the compressive strength as a function of porosity (Figure 3). Exponential equations [5-7] were found to properly fit these relations:

$$
\begin{gathered}
E_{d}[G P a]=92.67 \cdot \exp (-0.0593 n) \\
G[G P a]=33.86 \cdot \exp (-0.0562 n) \\
\sigma_{c}[M P a]=99.79 \cdot \exp (-0.0717 n)
\end{gathered}
$$

where $E_{d}$ and $G$ are the elastic and shear modulus, respectively; $\sigma_{c}$ is the compressive strength; and $n$ is the porosity in percent. Very high coefficients of determination $\left(\mathrm{R}^{2}\right)$ were obtained for these three relations (0.98 for Equations [5] and [6] and 0.96 for Equation [7]), indicating that these three mechanical properties are heavily dependent on the porosity of the material: increasing porosity leads to a significant reduction in the mechanical properties. Similar exponential correlations between these mechanical

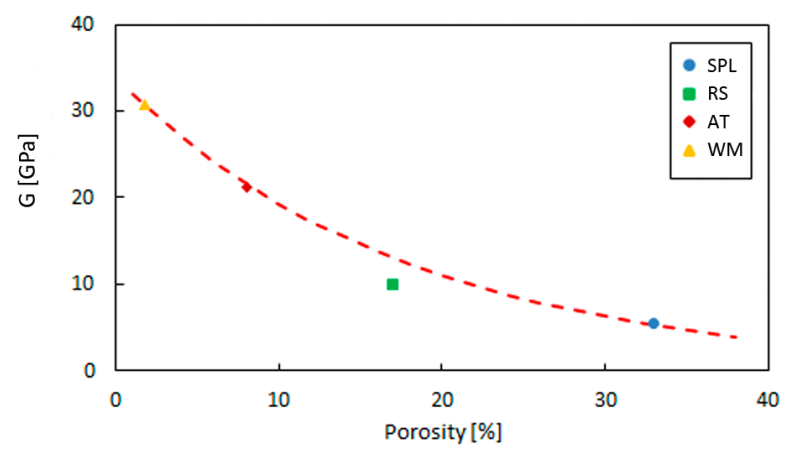

(b)

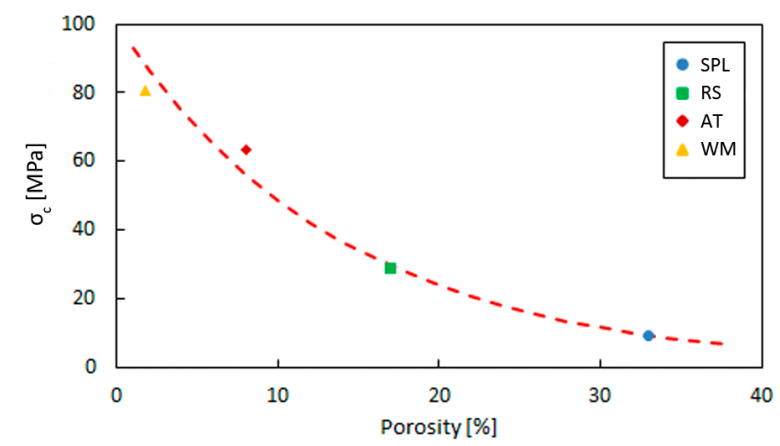

(c)

FiguRE 3. Modulus of elasticity (a), shear modulus (b) and compressive strength (c) as a function of porosity. 
parameters and porosity have also been suggested in previous studies regarding limestones and sandstones $(47,48)$ and even for other rock types, such as volcanic tuff, with very different porous systems and mineralogy (49).

Not only porosity but also grain size and pore size may have an effect on the mechanical properties of the samples. It is known that finer-grained rocks of the same type usually present higher strength and that coarse-grained rock generally has both low strength and low fracture toughness (45), as in the case of SPL. However, no further conclusions can be drawn in this regard, as other factors that are beyond the scope of this study, such as the grain size distribution and grain boundary shape, may affect the strength of the rocks.

It is also relevant to evaluate the relationship between the various mechanical properties. As the FFR method is able to determine the dynamic elastic and shear modulus, defining a correlation between these parameters and the compressive strength would make it possible to assess the latter from the results of the FFR tests. Actually, this has been one of the main aims of several studies regarding different types of NDTs $(21,22)$ Diverse authors have indicated linear or polynomic relations between $\sigma_{c}$ and $E_{d}$ for both metamorphic and sedimentary rocks (11, 50 ), while there is no thorough investigation regarding the relation between the compressive strength and the shear modulus. Although a good linear correlation was found in the present study $\left(\mathrm{R}^{2}\right.$ equal to ca. 0.90), a logarithmic equation was observed to

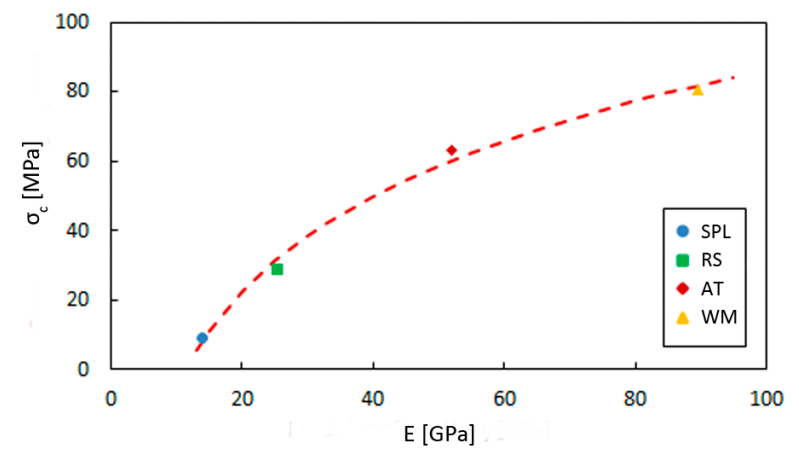

(a) better fit the results, obtaining $\mathrm{R}^{2}>0.99$ for both cases. These correlations are shown in Figure 4 according to Equations [8] and [9].

$$
\begin{gathered}
\sigma_{c}[M P a]=-96.23+39.61 \ln E_{d}[G P a] \\
\sigma_{c}[M P a]=-64.27+41.89 \ln G[G P a]
\end{gathered}
$$

with $E_{d}, G$ and $\sigma_{c}$ as previously defined for Equations [5-7].

\subsection{Test results in water-saturated conditions}

The comparison between the results in dry and wet conditions shows that the saturation of the pores causes a reduction in the natural frequencies, leading to a decrease in the modulus of elasticity and shear modulus, even though the material bulk density increases. These results are consistent with previous studies (51-54), proving the ability of the FFR method to properly identify the variation in the mechanical properties when varying the saturation condition of the samples.

The results shown in Table 5 highlight the fundamental role played by porosity in the variation of the material mechanical properties when increasing the moisture content. Rocks with low porosity, such as marble, have very small variations in their elastic and shear modulus values, while very porous rocks, such as limestone or sandstone, show a severe reduction in their mechanical properties due to the

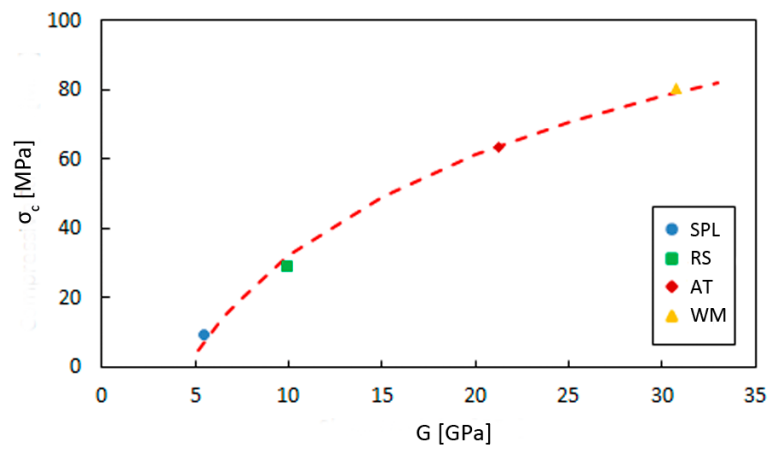

(b)

FIgURE 4. Compressive strength as a function of modulus of elasticity (a) and shear modulus (b).

TABLE 5. Mechanical properties obtained from FFR tests in saturated conditions and variation with respect to dry conditions, in parenthesis. Elastic modulus calculated via longitudinal $\left(E_{d, L}\right)$ and transversal $\left(E_{d, T}\right)$ mode and shear modulus $(G)$.

\begin{tabular}{lllllrl}
\hline Rock & \multicolumn{2}{c}{$E_{d, L}[\mathrm{GPa}]$} & \multicolumn{2}{c}{$E_{d, T}[\mathrm{GPa}]$} & \multicolumn{2}{c}{$G[\mathrm{GPa}]$} \\
\hline WM & 88.98 & $(-0.7 \%)$ & 84.81 & $(-0.2 \%)$ & 30.70 & $(-0.2 \%)$ \\
SPL & 12.30 & $(-11.7 \%)$ & 10.86 & $(-16.2 \%)$ & $4.77 \quad(-13.5 \%)$ \\
AT & 51.65 & $(-0.5 \%)$ & 47.92 & $(-2.0 \%)$ & $21.11 \quad(-0.7 \%)$ \\
RS & 20.05 & $(-21.3 \%)$ & 17.89 & $(-24.6 \%)$ & $7.24 \quad(-7.24 \%)$ \\
\hline
\end{tabular}


significant amount of water held inside the pores. This fact should be considered when evaluating the vulnerability of existing masonry structures, as an increase in the moisture content could dramatically reduce the material mechanical properties evaluated in dry conditions.

\section{CONCLUSIONS}

This paper presents the application of the freefree resonance nondestructive testing technique for calculating the mechanical properties of building stones as a useful method to assess material properties without destroying or damaging the sample.

The results obtained from the tests show that the porosity of carbonate rocks is the main factor influencing their mechanical behavior. An increase in the porosity drastically reduces the modulus of elasticity, shear modulus and compressive strength of the rocks. A strong exponential relationship between the porosity of the carbonate rocks and their elastic and shear modulus and compressive strength has been found. Additionally, a logarithmic correlation between both the elastic and shear modulus and the compressive strength of the rocks is observed.

The FFR method proves to be capable of detecting the reduction of the elastic and shear modulus due to the water saturation of the rocks, as the presence of the water held in the pores causes a significant decrease in the natural frequencies measured in the FFR tests. This effect, therefore, is more remarkable in materials with higher porosity.

As a general conclusion, the investigations carried out in the present study indicate that the FFR method is a valid and useful nondestructive tool to assess the mechanical properties of building stones.

\section{ACKNOWLEDGMENTS}

This work was supported by the Spanish Ministry of Universities via a doctoral grant to Fernando Ávila [FPU18/03607].

Special thanks to the Department of Mineralogy and Petrology of the University of Granada for the supply of the source materials and to Javier Román Ramos, M.Sc. student, for his excellent work during the conduction of the tests.

\section{AUTHOR CONTRIBUTIONS:}

Conceptualization: E. Puertas, R. Gallego. Data curation: F. Ávila. Formal analysis: F. Ávila. Funding acquisition: R. Gallego. Investigation: F. Ávila. Methodology: E. Puertas. Project administration: R. Gallego. Resources: R. Gallego. Software: E. Puertas. Supervision: E. Puertas, R. Gallego. Validation: E. Puer- tas, R. Gallego. Roles/Writing, original draft: F. Ávila. Writing, review \& editing: E. Puertas, R. Gallego.

\section{REFERENCES}

1. Yang, Y.; Zhan, B.; Wang, J.; Zhang, Y. (2020) Nondestructive assessment of the compressive strength of concrete with high volume slag. Mater. Charact. 162, 110223. https://doi. org/10.1016/j.matchar.2020.110223.

2. Işık, N.; Halifeoğlu, F.M.; İpek, S. (2020) Nondestructive testing techniques to evaluate the structural damage of historical city walls. Construc. Build. Mat. 253, 119228. https://doi.org/10.1016/j.conbuildmat.2020.119228.

3. Moropoulou, A.; Labropoulos, K.C.; Delegou, E.T.; Karoglou, M.; Bakolas, A. (2013) Non-destructive techniques as a tool for the protection of built cultural heritage. Construc. Build. Mat. 48, 1222-1239. https://doi.org/10.1016/j. conbuildmat.2013.03.044.

4. McCann, D.M.; Forde, M.C. (2001) Review of NDT methods in the assessment of concrete and masonry structures. NDT E Int. 34 [2], 71-84.

5. Kashif Ur Rehman, S.; Ibrahim, Z.; Memon, S.A.; Jameel, M. (2016) Nondestructive test methods for concrete bridges: A review. Construc. Build. Mat. 107, 58-86. https://doi. org/10.1016/j.conbuildmat.2015.12.011.

6. Wahab, A.; Aziz, M.M.A.; Sam, A.R.M.; You, K.Y.; Bhatti, A.Q.; Kassim, K.A. (2019) Review on microwave nondestructive testing techniques and its applications in concrete technology. Construc. Build. Mat. 209, 135-146. https://doi.org/10.1016/j.conbuildmat.2019.03.110.

7. Gomez-Heras, M.; Benavente, D.; Pla, C.; MartinezMartinez, J.; Fort, R.; Brotons, V. (2020) Ultrasonic pulse velocity as a way of improving uniaxial compressive strength estimations from Leeb hardness measurements. Construc. Build. Mat. 261, 119996. https://doi.org/10.1016/j. conbuildmat.2020.119996.

8. Forestieri, G.; Freire-Lista, D.M.; De Francesco, A.M.; Pontea, M.; Fort, R. (2017) Strength anisotropy in building granites. Int. J. Archit. Herit. 11 [8], 1153-1165. https://doi. org/10.1080/15583058.2017.1354096.

9. Karaman, K.; Kesimal, A. (2015) Correlation of schmidt rebound hardness with uniaxial compressive strength and p-wave velocity of rock materials. Arab. J. Sci. Eng. 40 [7], 1897-1906. https://doi.org/10.1007/s13369-014-1510-z.

10. Kurtulus, C.; CakIr, S.; Yoğurtcuoğlu, A.C. (2016) Ultrasound study of limestone rock physical and mechanical properties. Soil Mech. Found. Eng. 52 [6], 348-354. https:// doi.org/10.1007/s11204-016-9352-1.

11. Najibi, A.R.; Ghafoori, M.; Lashkaripour, G.R.; Asef, M.R. (2015) Empirical relations between strength and static and dynamic elastic properties of Asmari and Sarvak limestones, two main oil reservoirs in Iran. $J$. Pet. Sci. Eng. 126, 78-82. https://doi.org/10.1016/j. petrol.2014.12.010.

12. Freire-Lista, D.M.; Fort, R. (2017) Exfoliation microcracks in building granite. Implications for anisotropy. Eng. Geol. 220, 85-93. https://doi.org/10.1016/j.enggeo.2017.01.027.

13. Quagliarini, E.; Revel, G.M.; Lenci, S.; Seri, E.; Cavuto, A.; Pandarese, G. (2014) Historical plasters on light thin vaults: State of conservation assessment by a Hybrid ultrasonic method. J. Cult. Herit. 15 [2], 104-111. https://doi. org/10.1016/j.culher.2013.04.008.

14. Yalçıner, C.Ç.; Büyüksaraç, A.; Kurban, Y.C. (2019) Nondestructive damage analysis in Kariye (Chora) Museum as a cultural heritage building. J. Appl. Geophys. 171, 103874. https://doi.org/10.1016/j.jappgeo.2019.103874.

15. Breysse, D.; Klysz, G.; Dérobert, X.; Sirieix, C.; Lataste, J.F. (2008) How to combine several non-destructive techniques for a better assessment of concrete structures. Cem. Concr. Res. 38 [6], 783-793. https://doi.org/10.1016/j. cemconres.2008.01.016.

16. UNE-EN 14146:2004. Métodos de ensayo para piedra natural. Determinación del módulo de elasticidad dinámico (con la medida de la frecuencia de resonancia fundamental), (2004). 
17. Schaeffer, K.; Bearce, R.; Wang, J. (2013) Dynamic modulus and damping ratio measurements from free-free resonance and fixed-free resonant column procedures. $J$. Geotech. Geoenviron. Eng. 139 [12], 2145-2155. https://doi. org/10.1061/(ASCE)GT.1943-5606.0000945.

18. Guimond-Barrett, A.; Nauleau, E.; Le Kouby, A.; Pantet, A.; Reiffsteck, P.; Martineau, F. (2013) Free-free resonance testing of in situ deep mixed soils. Geotech. Test. J. 36 [2], 283-291.

19. Verástegui-Flores, R.D.; Di Emidio, G.; Bezuijen, A.; Vanwalleghem, J.; Kersemans, M. (2015) Evaluation of the free-free resonant frequency method to determine stiffness moduli of cement-treated soil. Soils Found. 55 [5], 943-950. https://doi.org/10.1016/j.sandf.2015.09.001.

20. Sun, C.; Tang, G.; Zhao, J.; Zhao, L.; Wang, S. (2018) An enhanced broad-frequency-band apparatus for dynamic measurement of elastic moduli and Poisson's ratio of rock samples. Rev. Sci. Instrum. 89, 064503. https://doi. org/10.1063/1.5018152.

21. Waqas, U.; Ahmed, M.F. (2020) Prediction modeling for the estimation of dynamic elastic young's modulus of thermally treated sedimentary rocks using linear-nonlinear regression analysis, regularization, and ANFIS. Rock Mech. Rock Eng. 53 [12], 5411-5428. https://doi.org/10.1007/s00603-02002219-8.

22. Lin, Y.; Peng, L.; Lei, M.; Wang, X.; Cao, C. (2019) Predicting the mechanical properties of bimrocks with high rock block proportions based on resonance testing technology and damage theory. Appl. Sci. 9 [17], 3537. https://doi. org/10.3390/app9173537.

23. Eiras, J.N.; Vu, Q.A.; Lott, M.; Payá, J.; Garnier, V.; Payan, C. (2016) Dynamic acousto-elastic test using continuous probe wave and transient vibration to investigate material nonlinearity. Ultrasonics. 69, 29-37. https://doi. org/10.1016/j.ultras.2016.03.008

24. Spalvier, A.; Domenech, L.D.; Cetrangolo, G.; Popovics, J.S. (2020) Torsional vibration technique for the acoustoelastic characterization of concrete. Mater. Struct. 53, 7. https://doi. org/10.1617/s11527-020-1438-6.

25. Arizzi, A.; Belfiore, C.M.; Cultrone, G.; Rodríguez-Navarro, C.; Sebastián-Pardo, E.; Triscari, M. (2007) Petro-chemical and physical investigations on the "Santa Pudia Calcarenite" (Andalusia, Spain): New hints for the prevention and conservation of calcarenitic building materials. Goldschmidt Conf. Abstr. A35. Retrieved from https://goldschmidtabstracts. info/2007/35.pdf.

26. Luque, A.; Cultrone, G.; Mosch, S.; Siegesmund, S.; Sebastian, E.; Leiss, B. (2010) Anisotropic behaviour of white macael marble used in the Alhambra of Granada (Spain). The role of thermohydric expansion in stone durability. Eng. Geol. 115 [3-4], 209-216. https://doi.org/10.1016/j. enggeo.2009.06.015

27. Molina, E.; Benavente, D.; Sebastian, E.; Cultrone, G. (2015) The influence of rock fabric in the durability of two sandstones used in the Andalusian Architectural Heritage (Montoro and Ronda, Spain). Eng. Geol. 197, 67-81. https:// doi.org/10.1016/j.enggeo.2015.08.009.

28. Urosevic, M.; Sebastián Pardo, E.; Ruiz-Agudo, E.; Cardell, C. (2011) Physical properties of carbonate rocks used as a modern and historic construction material in Eastern Andalusia, Spain. Mater. Construcc. 61 [301], 93-114. https://doi.org/10.3989/mc.2010.53809.

29. Balanyá, J.C.; García-Dueñas, V. (1986) Grandes fallas de contracción y de extensión implicadas en el contacto entre los dominios de Alborán y Sudibérico en el arco de Gibraltar. Geogaceta. 1, 19-21.

30. López Sánchez-Vizcaóno, V.; Connolly, J.A.D.; GómezPugnaire, M.T. (1997) Metamorphism and phase relations in carbonate rocks from the Nevado-Filábride Complex (Cordilleras Béticas, Spain): Application of the Ttn + Rt + $\mathrm{Cal}+\mathrm{Qtz}+\mathrm{Gr}$ buffer. Contrib. to Mineral. Petrol. 126 [3], 292-302. https://doi.org/10.1007/s004100050251.

31. Miras, A.; Vázquez, M.A.; Galán, E.; Apostolaki, C.; Marcopoulos, T. (2009) Sustainability criteria for the selection of marble to be used for restoration: application to the Alhambra Palace (Granada, Spain). In A. Gutiérrez García-M, P. Lapuente Mercadal, \& I. Rodà de Llanza (Eds.)
Interdisciplinary Studies on Ancient Stone: proceedings of the IX Association for the Study of Marble and Other Stones in Antiquity. (ASMOSIA) Conference (pp. 1-6). Instituto Catalán de Arqueología Clásica.

32. Navarro, R.; Pereira, D.; Cruz, A.S.; Carrillo, G. (2019) The Significance of "White Macael" marble since ancient times: characteristics of a candidate as global heritage stone resource. Geoheritage. 11, 113-123. https://doi.org/10.1007/ s12371-017-0264-x.

33. Vázquez, P.;Alonso, F.J.; Carrizo, L.; Molina, E.; Cultrone, G.; Blanco, M.; Zamora, I. (2013) Evaluation of the petrophysical properties of sedimentary building stones in order to establish quality criteria. Construc. Build. Mat. 41, 868-878. https:// doi.org/10.1016/j.conbuildmat.2012.12.026

34. García del Cura, M.A.; Sanz-Montero, E.; Benavente, D.; Martínez-Martínez, J.; Bernabéu, A. (2008) Sistemas travertínicos de Alhama de Almería: características petrográficas y petrofísicas. Geotemas. 10, 456-459.

35. UNE-EN 13755. Métodos de ensayo para piedra natural. Determinación de la absorción de agua a presión atmosférica, (2008).

36. UNE-EN 1926. Métodos de ensayo para la piedra natural. Determinación de la resistencia a la compresión uniaxial, (2007).

37. Demirdag, S.; Tufekci, K.; Kayacan, R.; Yavuz, H.; Altindag, R. (2010) Dynamic mechanical behavior of some carbonate rocks. Int. J. Rock Mech. Min. Sci. 47 [2], 307-312. https:// doi.org/10.1016/j.ijrmms.2009.12.003.

38. Martínez-Soto, F.; Puertas, E.; Gallego, R.; Suarez, F.J. (2018) Using spectral analysis of surface waves to characterize construction materials in built cultural heritage: the church of Saint Justo \& Pastor. 6th Int. Conf. on Herit. Sustain. Develop., 2, 1407-1417. Retrieved from https:// www.researchgate.net/publication/322065481.

39. Molina-Piernas, E. (2015). Influencia de la textura, del sistema poroso y del acabado superficial en la durabilidad de areniscas y travertino explotados en Andalucía y utilizados en construcción [Universidad de Granada]. Retrieved from http://hdl.handle.net/10481/40320.

40. Sarpün, I.H.; Özkan, V.; Tuncel, S. (2009) Ultrasonic determination of elastic modulus of marbles relation with porosity and $\mathrm{CaO} \%$. 10th Int. Conf. Slov. Soc. NonDestructive Test. 119-125.

41. ASTM International. (2014) C215-14 standard test method for fundamental transverse, longitudinal, and torsional resonant frequencies of concrete specimens. In Am. Soc. Test. Mater.

42. Molina, E.; Cultrone, G.; Sebastián, E; Alonso, F.J. (2013) Evaluation of stone durability using a combination of ultrasound, mechanical and accelerated aging tests. $J$. Geophys. Engineer. 10 [3], 035003. https://doi. org/10.1088/1742-2132/10/3/035003.

43. Justo, J.; Castro, J. (2021) Mechanical properties of 4 rocks at different temperatures and fracture assessment using the strain energy density criterion. Geomech. Energy Environ. 25, 100212. https://doi.org/10.1016/j.gete.2020.100212.

44. Rodríguez Gordillo, J.; Sáez Pérez, M.P. (2010) Performance of Spanish white Macael marble exposed to narrow- and medium-range temperature cycling. Mater. Construcc. 60 [297], 127-141. https://doi.org/10.3989/mc.2010.44107.

45. Lindqvist, J.E.; Åkesson, U.; Malaga, K. (2007) Microstructure and functional properties of rock materials. Mater. Charact. 58 [11-12], 1183-1188. https://doi. org/10.1016/j.matchar.2007.04.012.

46. Del Río, L.M.; López, F.; Calleja, B.; Tejado, J.J.; Mota, M.I.; González, I.; San Emeterio, J.L.; Ramos, A. (2007) Resonance-based acoustic technique applied to the determination of Young's modulus in granites. 19th Int. Congr. Acoust. Retrieved from http://www.sea-acustica.es/ WEB_ICA_07/fchrs/papers/ult-17-017.pdf.

47. Sabatakakis, N.; Koukis, G.; Tsiambaos, G.; Papanakli, S. (2008) Index properties and strength variation controlled by microstructure for sedimentary rocks. Eng. Geol. 97 [1-2], 80-90. https://doi.org/10.1016/j.enggeo.2007.12.004.

48. Tuğrul, A. (2004) The effect of weathering on pore geometry and compressive strength of selected rock types from Turkey. Eng. Geol. 75 [3-4], 215-227. https://doi.org/10.1016/j. enggeo.2004.05.008. 
49. Pappalardo, G.; Punturo, R.; Mineo, S.; Contrafatto, L. (2017) The role of porosity on the engineering geological properties of 1669 lavas from Mount Etna. Eng. Geol. 221, 16-28. https://doi.org/10.1016/j.enggeo.2017.02.020.

50. Chang, C.; Zoback, M.D.; Khaksar, A. (2006) Empirical relations between rock strength and physical properties in sedimentary rocks. J. Pet. Sci. Eng. 51 [3-4], 223-237. https://doi.org/10.1016/j.petrol.2006.01.003.

51. Gu, D.M.; Huang, D.; Zhang, W.G.; Gao, X.C.; Yang, C. (2020) A 2D DEM-based approach for modeling waterinduced degradation of carbonate rock. Int. J. Rock Mech. Min. Sci. 126, 104188. https://doi.org/10.1016/j. ijrmms.2019.104188

52. Vales, F.; Minh, D.; Gharbi, H.; Rejeb, A. (2004) Experimental study of the influence of the degree of saturation on physical and mechanical properties in Tournemire shale (France). Appl. Clay Sci. 26 [1-4], 197-207. https://doi.org/10.1016/j. clay.2003.12.032.

53. Van Den Abeele, K.E.A.; Carmeliet, J.; Johnson, P.A.; Zinszner, B. (2002) Influence of water saturation on the nonlinear elastic mesoscopic response in Earth materials and the implications to the mechanism of nonlinearity. J. Geophys. Res. 107 [B6], 1-11. https://doi. org/10.1029/2001jb000368.

54. Ciantia, M.O.; Castellanza, R.; di Prisco, C. (2015) Experimental study on the water-induced weakening of calcarenites. Rock Mech. Rock Eng. 48, 441-461. https://doi. org/10.1007/s00603-014-0603-z. 